http://journal.uin-alauddin.ac.id/index.php/lamaisyir

Publisher: Fakultas Ekonomi dan Bisnis Islam UIN Alauddin Makassar

\title{
Exploring Sharia Screening Review in Islamic Capital Market in Indonesia (Jakarta Islamic Index)
}

\author{
1Mustakim Muchlis, ${ }^{2}$ Abdul Hamid Habbe \\ ${ }^{1}$ UIN Alauddin Makassar, ${ }^{2}$ Universitas Hasanuddin \\ Jl. Sultan Alauddin, Kabupaten Gowa, Sulawesi Selatan ${ }^{1}$, Jl. Perintis Kemerdekaan, \\ Kota Makassar, Sulawesi Selatan ${ }^{2}$ \\ 1'mustakim.muchlis@uin-alauddin.ac.id, ${ }^{2}$ hamidhabbe@gmail.com \\ Received: 18 March 2021; Revised: 18 Mach 2021; Published: 12 April 2021
}

\begin{abstract}
ABSTRAK
Beberapa penelitian terdahulu terkait screening pasar modal syariah belum banyak yang melakukan eksplorasi secara mendalam terhadap screening syariah pada indeks disuatu negara selama beberapa kurun waktu. Penelitian ini bertujuan mengeksplorasi screening syariah yang dilakukan pada entitas yang terdaftar di Jakarta Islamic (JII) Index tahun 2015- 2019. Penelitian menggunakan pendekatan quantitative deskriptif dengan menganalisa dan mendeskripsikan screening syariah pada entitas yang terdaftar di JII. Temuan penelitian menunjukkan bahwa Otoritas Jasa Keuangan telah melakukan screening syariah dengan baik pada entitas yang terdaftar sesuai dengan kriteria yang ditetapkan, hal ini dibuktikan dengan melihat aspek qualitative entitas yang tidak menjalankan aktivitas yang mengandung unsur riba, gharar, dan maysir. Sementara pada aspek quantitative, entitas telah mengikuti kesesuaian antara besaran persentase utang berbasis bunga tidak lebih dari 45 persen dan pendapatan non halal tidak lebih dari 10 persen. Namun kriteria yang ditetapkan OJK dan MUI masih terdapat beberapa kelemahan jika dibandingkan dengan kriteria screening yang berlaku di negara lain.
\end{abstract}

Kata Kunci: Pasar modal syariah; Screening syariah.

\section{ABSTRACT}

Several previous studies on Islamic capital market screening have not conducted an indepth exploration of Sharia screening on a country's index over different periods. This study aims to examine sharia screening performed on entities registered in the Jakarta Islamic (JII) Index 2015-2019. The study uses a descriptive quantitative approach by analyzing and describing Sharia screening in entities registered in JII. The research results show that the Financial Services Authority has properly screened Sharia law in registered entities according to the established criteria, as evidenced by looking at the qualitative aspects of entities that do not carry out activities that contain elements of usury, gharar, and maysir. Meanwhile, in the quantitative aspect, the entity has tracked the appropriateness between the percentage of interest-based debt of no more than 45 percent and non-halal income of no more than 10 percent. However, the OJK and MUI criteria still show some weaknesses compared to the screening criteria that apply in other countries

Key word: Islamic capital market; Sharia Screening. 
Mustakim M: Islamic capital market; Sharia Screening.

\section{PENDAHULUAN}

Pasar modal syariah secara umum sama dengan pasar modal non syariah, yang membedakan diantara keduanya yakni adanya produk dan mekanisme transaksi yang tidak bertentangan dengan prinsip syariah pada pasar modal syariah. Meskipun demikian, entitas yang masuk ke dalam pasar modal syariah bukanlah entitas yang melaksanakan operasional berdasarakan prinsip syariah. Hal ini dapat dilihat pada penerbitan Daftar Efek Syariah (DES) pada tahun 2020 di Indonesia, terdapat 436 saham syariah yang diterbitkan namun hanya 5 yang merupakan entitas syariah. Sisanya adalah entitas yang menjalankan operasionalnya tidak berdasarkan prinsip syariah, namun memenuhi kriteria sebagai saham syariah.

Otoritas Jasa Keuangan (OJK) sebagai pihak yang senantiasa mendorong pengembangan pasar modal syariah di Indonesia memiliki tanggungjawab melakukan seleksi (screening) terhadap setiap emiten yang akan masuk kedalam pasar modal syariah. OJK melakukan screening syariah pada dua aspek yakni quantitative dan qualitative. Pada aspek quantitaive dilakukan pemeriksaan terkait tingkat utang berbasis bunga, likuiditas, investasi atau pendapatan berbasis bunga suatu entitas yang dimana dalam perspektif Islam hal tersebut dilarang (Ayedh et al., 2019). Pada aspek qualitative OJK melihat apakah entitas tidak terlibat dalam aktivitas terlarang seperti produksi barang/jasa terlarang, praktik perjudian, dan aktivitas lainnya yang tidak diperbolehkan dalam Islam. Screening syariah dilakukan guna melindungi hak investor dalam berinvestasi pada entitas yang tidak hanya berfokus pada keuangan, tetapi juga pada kegiatan bisnis entitas yang sesuai dengan syariah (Derigs \& Marzban, 2008).

Terdapat beberapa penelitian yang meneliti terkait pelaksanan screening syariah pada pasar modal syariah diantaranya Firmansyarh (2017), yang membandingkan pelaksanaan praktik screening pasar modal syariah Indonesia dan Malayasia. Hasil penelitian menemukan terdapat perbedaan kriteria dalam melakukan seleksi antara masing-masing negara yang didasarkan pada pemahaman terhadap paham yang dianut. Penelitian yang dilakukan oleh Ramdani (2018) yang mengkaji perbedaan model screening serta penyebab terjadinya perbedaan pada beberapa indeks sepri DJIM index, MSCI dan indekx lainnya, penelitian menemukan adanya perbedaan model dan dan batasan dalam kriteria screening antara indeks yang diteliti. Perbedaan tersebut terjadi dikarenakan berbedanya sudut pandangan, prosedur dan pedoman yang digunakan. Sementara itu penelitian yang dilakukan oleh Ayedh et al., (2019) mengeksplorasi dan menganalisis secara kritis perbandingan metodologi screening antara indeks syariah utama di dunia. Penelitian tersebut didapatkan 
terjadinya perbedaan penilaian baik dari segi qualitative maupun quantitative. Penelitian ini juga memberikan masukan untuk pembuat kebijakan di setiap negara untuk memastikan praktik screening syariah dan peningkatan standarisasi screening syariah di antara indeks utama syariah.

Beberapa penelitian terdahulu terkait screening pasar modal syariah belum banyak yang melakukan eksplorasi lebih lanjut secara mendalam terhadap screening syariah pada satu indeks disuatu negara selama beberapa kurun waktu, terutama pasar pasar modal syariah di Indonesia. Hal inilah yang memotiviasi peneliti untuk melakukan penelitian lebih lanjut dan mendalam terkait pelaksanaan screening di salah satu indeks di suatu negara dalam hal ini di Indonesia pada periode 2015-2019. Selain itu penelitian ini juga akan memperlihatkan entitas jenis apa saja dan bergerak pada bidang apa saja entitas yang terdaftar dari kurun waktu tersebut dan melihat tingkat utang berbasis bunga dan pendapatan non-halal yang terjadi pada entitas yang terdaftar di JII. Penelitian ini bertujuan memaparkan konsep screening syariah yang dilakukan di Indonesia dengan melihat penerapan aturan-aturan screening tersebut baik secara qualitative dan quantitative pada entitas yang terdaftar di Jakarta Islamic Index.

\section{METODE PENELITIAN}

Penelitian ini merupakan penelitian kuantitatif deskriptif, dimana peneliti memberikan gambaran atas suatu kondisi berdasarkan data yang diperoleh dari entitas. Metode ini digunakan sebab dianggap tepat dalam memberikan gambaran atas data-data keuangan dan non keuangan dari laporan tahunan entitas. Penelitian ini mengambil sampel yang difokuskan pada entitas yang terdaftar selama lima tahun berturut-turut (2015-2019) di Jakrta Islamic Index (JII). JII merilis 30 entitas yang paling likuid tiap 6 bulan sekali, dan dari 30 entitas tersebut terdapat entitas yang keluar masuk dari daftar listing JII, sehingga hanya tersedia 17 entitas yang dapat di analisis datanya. Tabel 2. memperlihatkan daftar entitas dan bidang usaha yang diijalankan.

Penelitian ini menggunakan data persentase utang berbasis bunga yang di peroleh dari: 
Mustakim M: Islamic capital market; Sharia Screening.

$$
\% U B B=\frac{U B B}{T A}
$$

Dimana:

$\mathrm{UBB}=$ Utang Berbasis Bunga

$\mathrm{TA}=$ Total Aset

Untuk data persentase pendapatan non halal diperoleh dari:

Dimana:

$$
\% P N H=\frac{P N H}{T P}
$$

PNH = Pendapatan non halal

$\mathrm{TP}=$ Total pendapatan

Kedua persamaan di atas digunakan berdasarkan aturan yang telah ditetapkan oleh Otoritas Jasa Keuangan yang menyatakan bahwa utang berbasis bunga tidak lebih dari 45\% yng diperoleh dari jumlah utang berbasis bunga dibagi dengan total aset. Pendapatan non halal tidak lebih dari 10\% diperoleh dari jumlah pendapatan non halal dibagi dengan total pendapatan entitas. Data keuangan tersebut diperoleh dari website Bursa Efek Indonesia.

\section{HASIL PENELITIAN DAN PEMBAHASAN}

Model screening shariah yang berlaku di dunia sangat banyak, misalnya DJIM Index, FTSE Islamic Index, MSCI Islamic Index dan SAC (SC). Banyaknya model screening syariah dipengaruhi oleh beberapa faktor diantaranya adalah perbedaan struktur masyarakat setiap negara. Selain itu, mazhab yang dianut suatu negara juga sangat memengaruhi model screening syariah yang digunakan. Negara dengan mayoritas masayarakatnya adalah Muslim pastinya memiliki banyak ahli syariah. Hal ini akan membuat negara tersebut akan menggunakan model screening yang spesisifik dan berlakunya hanya di negara tersebut, misalnya Indonesia (Ardiansyah et al., 2017; Ramdani \& Ahmad Amir Aziz, 2018).

Pelaksanaan screening syariah di Indonesia berpedoman pada Peraturan Otoritas Jasa Keuangan Nomor 15/PJOK.04/2015 dan Fatwa Dewan Syariah Nasional No: 40/DSN-MUI/X/2003 tentang Pasar Modal dan Pedoman Umum Penerapan Prinsip Syariah Di Bidang Pasar Modal. Menurut aturan-aturan 
tersebut, suatu entitas dapat masuk ke dalam saham syariah jika telah dinyatakan lulus screening yang dilakukan baik secara qualitative maupun quantitative.

Qualitative screening adalah penyaringan yang dilakukan kepada entitas yang masuk ke dalam saham syariah dengan melihat aspek-aspek kepatuhan syariah pada bisnis yang dijalankan. Syariah dengan jelas melarang aspek-aspek yang tidak diperbolehkan oleh umat Islam, seperti memproduksi alkohol, daging babi, dan sebagainya. Sehingga entitas yang ingin masuk ke dalam saham syariah tidak diperbolehkan untuk mendapatkan penghasilan utama atau bahkan sebagian penghasilan bersumber dari kegiatan tersebut (Derigs \& Marzban, 2008).

Di Indonesia, qualitative screening dilakukan dengan mengikuti kriteria sebagai berikut:

Tabel 1. Kriteria Screening Menurut Fatwa DSN-MUI dan Otoritas Jasa Keuangan Terhadap Kegiatan Bertentangan dengan Syariah

\begin{tabular}{|c|c|}
\hline DSN- & angan \\
\hline$\overline{J-M U I ~ I ~}$ & Peraturan Otc \\
\hline 2003 Pasa & Nomor 35/POJK.04/2017 Te1 \\
\hline Emiten yang Menerbitkan Efek & Kriteria dan $\mathrm{F}$ \\
\hline Syar & \\
\hline Idian dan & permainan \\
\hline long judi ata & \\
\hline larang; & ibawi; \\
\hline $\begin{array}{l}\text { b. lembaga keuangan konvensional } \\
\text { (ribawi), termasuk perbankan } \\
\text { dan asuransi konvensional; }\end{array}$ & $\begin{array}{l}\text { c. jual beli ris } \\
\text { unsur ke } \\
\text { dan/atau j }\end{array}$ \\
\hline $\begin{array}{l}\text { c. produsen, distributor, serta } \\
\text { pedagang makanan dan } \\
\text { minuman yang haram; dan }\end{array}$ & $\begin{array}{l}\text { d. memproduksi, mendistribusikan, } \\
\text { memperdagangkan, dan/atau } \\
\text { menyediakan: }\end{array}$ \\
\hline $\begin{array}{l}\text { d. produsen, distributor, dan/atau } \\
\text { penyedia barang-barang ataupun }\end{array}$ & sa haram zatnya \\
\hline jasa yang meru & isa haran \\
\hline ifat mudarat. & karena $\mathrm{zc}$ \\
\hline e. melakukan investasi & ghairihi) ya \\
\hline Emiten (perusahaan) yang pada & Dewan Syariah Nasional \\
\hline transaksi & a Indonesia; \\
\hline perusa & \\
\hline
\end{tabular}


Mustakim M: Islamic capital market; Sharia Screening.

\begin{tabular}{|c|c|}
\hline $\begin{array}{l}\text { lembaga keuangan ribawi lebih } \\
\text { dominan dari modalnya; }\end{array}$ & $\begin{array}{l}\text { 3. barang atau jasa yang } \\
\text { merusak moral dan bersifat } \\
\text { mudarat; dan/atau } \\
\text { 4. barang atau jasa lainnya yang } \\
\text { bertentangan dengan prinsip } \\
\text { syariah berdasarkan } \\
\text { ketetapan dari Dewan Syariah } \\
\text { Nasional - Majelis Ulama } \\
\text { Indonesia; } \\
\text { e. dan melakukan kegiatan lain } \\
\text { yang bertentangan dengan } \\
\text { prinsip syariah berdasarkan } \\
\text { ketetapan dari Dewan Syariah } \\
\text { Nasional - Majelis Ulama } \\
\text { Indonesia; }\end{array}$ \\
\hline
\end{tabular}

Sumber: Fatwa DSN-MUI dan Peraturan Otoritas Jasa Keuangan

Quantitative Screening adalah penilaian yang dilakukan dalam hal keuangan untuk menilai kelayakan suatu entitas masuk ke dalam bursa saham syariah. Secara umum, kriteria quantitavie screening menyoroti tiga aspek yaitu tingkat utang yang berbasis bunga, pendapatan bunga, dan sejauh mana kas dan piutang entitas. Adapun tingkat toleransi berfokus pada masalah keadilan (Sani dan Othman, 2013).

Di Indonesia, quantitative screening didasarkan pada Peraturan Otoritas Jasa Keuangan Nomor 35/POJK.04/2017 Tentang Kriteria dan Penerbitan Daftar Efek Syariah yaitu memenuhi persentase keuangan yakni total utang yang berbasis bunga dibandingkan dengan total aset tidak boleh lebih dari $45 \%$ (empat puluh lima persen). Sementara untuk total pendapatan bunga dan pendapatan tidak halal lainnya dibandingkan dengan total pendapatan usaha dan pendapatan lain-lain tidak boleh lebih dari 10\% (sepuluh persen).

Aturan-aturan dalam quantitative screening ini adalah hal yang paling sering diperdebatkan (Derigs dan Marzban, 2008). Hal ini disebabkan Al-Qur'an dan Hadits tidak menyatakan secara langsung besaran dan ambang batas untuk analisis keuangan yang dapat diterima. Sehingga para ulama dan pembuat peraturan yang menafsirkan batasan untuk menilai kriteria quantitative entitas. 


\section{Analisis Screening Syariah pada entitas yang terdaftar di JII}

Untuk menggambarkan screening syariah yang dilakukan di Indonesia, kami melakukan pengujian terhadap perusahan yang listing di JII tahun 20152019. Entitas-entitas yang terdaftar di JII dipilih karena merupakan entitasentitas yang memiliki saham paling likuid. Terdapat 17 entitas yang listing di Jakarta Islamic Index dari tahun 2015 - 2019 yang tidak pernah keluar dari listing. Setiap enam bulan sekali OJK melakukan screening untuk melihat apakah entitasentitas yang terdaftar telah memenuhi kriteria secara qualitative dan quantitative untuk masuk ke dalam JII.

Penelitian ini akan melihat Qualitative Screening dan Quantitative Screening berdasarkan Peraturan Otoritas Jasa Keuangan Nomor 15/PJOK.04/2015 (Otoritas Jasa Keuangan, 2015) tentang penerbitan dan persyaratan efek beragun aset syariah dan Fatwa Dewan Syariah Nasional No: 40/DSN-MUI/X/2003 (Syariah, 2003) tentang Pasar Modal dan Pedoman Umum Penerapan Prinsip Syariah Di Bidang Pasar Modal.

Tabel 2. Daftar Entitas yang Terdaftar di Jakarta Islamic Index (JII) Tahun 2015 - 2019

\begin{tabular}{|c|c|c|}
\hline $\begin{array}{l}\text { Nama } \\
\text { Entitas }\end{array}$ & Bidang Usaha & Utama Entitas \\
\hline $\begin{array}{l}\text { Adaro } \\
(\mathrm{ADRO})\end{array}$ & Pertambangan & Batu Bara \\
\hline $\begin{array}{ll}\text { PT. } & \text { AKR } \\
\text { Corporindo } & \text { Tbk. } \\
\text { (AKRA) } & \end{array}$ & $\begin{array}{l}\text { Perdagangan } \\
\text { Investasi }\end{array}$ & $\begin{array}{l}\text { Perdagangan dan distribusi } \\
\text { minyak bumi dan bahan dasar } \\
\text { kimia }\end{array}$ \\
\hline $\begin{array}{lr}\text { PT. } & \text { Aneka } \\
\text { Tambang } & \text { Tbk. } \\
\text { (ANTM) } & \end{array}$ & Pertambangan & $\begin{array}{l}\text { Eksplorasi, penambangan, } \\
\text { pengolah, serta pemasaran } \\
\text { sumber daya mineral }\end{array}$ \\
\hline $\begin{array}{l}\text { Astra } \\
\text { (ASII) }\end{array}$ & Aneka Industri & $\begin{array}{l}\text { Operations dengan produk } \\
\text { sepeda motor Honda. }\end{array}$ \\
\hline PT. Bumi Serpong & Properti dan Real Estate & Pengembangan real estat \\
\hline $\begin{array}{ll}\text { Damai } & \text { Tbk. } \\
\text { (BSDE) } & \end{array}$ & & \\
\hline $\begin{array}{l}\text { PT. Indofood CBP } \\
\text { Sukses Makmur } \\
\text { Tbk. (ICBP) }\end{array}$ & $\begin{array}{l}\text { Industri } \\
\text { Konsumsi }\end{array}$ & $\begin{array}{l}\text { Memproduksi mie, produk } \\
\text { susu, makanan ringan, } \\
\text { penyedap makanan, nutrisi dan }\end{array}$ \\
\hline & & $\begin{array}{l}\text { makanan khusus, serta } \\
\text { minuman. }\end{array}$ \\
\hline
\end{tabular}


Mustakim M: Islamic capital market; Sharia Screening.

\begin{tabular}{|c|c|c|c|}
\hline $\begin{array}{lr}\text { PT. } & \text { Vale } \\
\text { Indonesia } & \text { TBK. } \\
\text { (INCO) } & \end{array}$ & $\mathrm{n}$ & & $\begin{array}{l}\text { Perusahaan tambang dan } \\
\text { pengoah nikel yang terintegrasi. }\end{array}$ \\
\hline Indofood (INDF) & $\begin{array}{l}\text { Industri } \\
\text { Konsumsi }\end{array}$ & Barang & $\begin{array}{l}\text { Berbagai jenis makanan dan } \\
\text { minuman }\end{array}$ \\
\hline $\begin{array}{l}\text { PT. Kalbe Farma } \\
\text { Tbk. (KLBF) }\end{array}$ & $\begin{array}{l}\text { Industri } \\
\text { Konsumsi }\end{array}$ & rang & $\begin{array}{l}\text { Memproduksi farmasi, } \\
\text { suplemen, nutrisi dan layanan } \\
\text { kesehatan }\end{array}$ \\
\hline $\begin{array}{l}\text { Matahari } \\
\text { Departement } \\
\text { Store (LPPF) }\end{array}$ & $\begin{array}{l}\text { Perdagangan } \\
\text { Investasi }\end{array}$ & Jasa & $\begin{array}{l}\text { Gerai serba ada yang } \\
\text { menyediakan berbagai macam } \\
\text { barang seperti pakaian, } \\
\text { aksesoris, tas, sepatu, kosmetik, } \\
\text { peralatan rumah tangga dan } \\
\text { mainan serta jasa konsultan } \\
\text { manajemen }\end{array}$ \\
\hline $\begin{array}{l}\text { PT. Bukit Asam } \\
\text { Tbk. (PTBA) }\end{array}$ & ibangan & & gan batu bara \\
\hline $\begin{array}{l}\text { PT. Pembangunan } \\
\text { Perumahaan } \\
\text { (PTPP) }\end{array}$ & ti dan Real & & $\begin{array}{l}\text { Perencanaan dan konstruksi } \\
\text { bangunan. }\end{array}$ \\
\hline $\begin{array}{lr}\text { PT. } & \text { Semen } \\
\text { Indoensia } & \text { Tbk. } \\
\text { (SMGR) } & \end{array}$ & $\begin{array}{l}\text { Industri Dasar } \\
\text { Kimia }\end{array}$ & $\operatorname{lan}$ & isen semen. \\
\hline $\begin{array}{l}\text { PT. Telkom } \\
\text { Indonesia (TLKM) }\end{array}$ & $\begin{array}{l}\text { Instruktur } \\
\text { Transportasi }\end{array}$ & as & $\begin{array}{l}\text { Perusahaan informasi dan } \\
\text { komunikasi serta penyedia jasa } \\
\text { dan jaringan telekomunikasi } \\
\text { secara lengkap }\end{array}$ \\
\hline $\begin{array}{l}\text { PT } \\
\text { Tractors } \\
\text { (UNTR) }\end{array}$ & $\begin{array}{l}\text { Perdagangan } \\
\text { Investasi }\end{array}$ & Jasa & $\begin{array}{l}\text { Distributor peralatan berat } \\
\text { terbesar dan terkemuka di } \\
\text { Indonesia yang menyediakan } \\
\text { produk-produk dari merek } \\
\text { ternama dunia yaitu Komatsu, } \\
\text { UD Trucks, Scania, Bomag, dan } \\
\text { Tadano. }\end{array}$ \\
\hline $\begin{array}{l}\text { Unilever } \\
\text { Indonesia } \\
\text { (UNVR) }\end{array}$ & $\begin{array}{l}\text { Industri } \\
\text { Konsumsi }\end{array}$ & ang & $\begin{array}{l}\text { Memproduksi kebutuhan } \\
\text { sehari-sehari seperti sabun, } \\
\text { shampoo, kecap, dll. }\end{array}$ \\
\hline
\end{tabular}


PT Wijaya Karya Properti dan Real Estate Bergerak dibidang kontraktor Tbk. (WIKA) konstruksi

Sumber: Laporan Tahunan masing-masing Entitas

\section{Qualitative Screening Entitas yang terdaftar di JII}

Qualitative screening entitas merujuk pada aktivitas utama entitas bukanlah dari aktivitas yang dilarang oleh agama, seperti memproduksi alkohol, lembaga keuangan ribawi, kegiatan yang mengandung unsur ketidakpastian (gharar), dan sebagainya.

Entitas yang terdaftar di JII selama periode 2015 - 2019 tidak melakukan kegiatan-kegiatan utama yang dilarang dalam Islam berdasarkan peraturan MUI dan OJK yang telah ditetapkan (lihat Tabel 1). Sementara Tabel 2 dapat memberikan gambaran mengenai entitas yang terdaftar dan kegiatan utama yang dilakukan. Terdapat entitas yang memproduksi makanan dan minuman, serta produk-produk yang dipakai langsung, seperti PT. Indofood dan Unilever, perusahan telah melengkapi semua produknya dengan sertifikasi halal. Unilever sendiri telah mensertifaksi halal 8 pabriknya untuk menjamin kehalalan produk yang dikeluarkan sehingga meningkat kepercayaan para konsumen khususnya yang beragama Islam.

Pelaksanaan qualitative screening idealnya tidak hanya menilai terkait halal haram kegiatan entitas. Suatu entitas bisa saja memproduksi barang dan jasa yang secara zatnya tidak mengandung keharaman namun bisa saja dalam proses produksinya terdapat kesalahan atau pelanggaran terhadap prinsip syariah. Ada beberapa aspek yang juga dapat dijadikan pertimbangan suatu entitas dikategorikan telah patuh terhadap syariah. Salah satu aspeknya adalah masalah lingkungan. Islam sesungguhnya sangat perhatian terhadap lingkungan, sebagaimana firman Allah dalam QS. Al Baqarah ayat 11 yang artinya:" Dan bila dikatakan kepada mereka: "Janganlah kamu membuat kerusakan di muka bumi". Mereka menjawab: "Sesungguhnya kami orang-orang yang mengadakan perbaikan" (Q.S. Al Baqarah :11)

Wilson (1997) menyatakan bahwa keuangan Islam tidak hanya berbicara mengenai halal dan haram. Terdapat etika dalam investasi yang juga harus diperhatikan. Etika investasi ini melibatkan sifat barang atau jasa entitas, lokasi entitas tersebut, kegiatan dalam memasarkan produk, dan sebagainya. Entitas Unilever misalnya yang mendukung LGBT yang jelas-jelas dilarang oleh Islam. Secara etika, Unilever sudah jauh dari prinsip syariah untuk masuk ke dalam 
Mustakim M: Islamic capital market; Sharia Screening.

saham syariah. Namun karena tidak dipersyaratkan dalam aturan yang ditetapkan oleh OJK dan MUI, maka Unilever tetap dalam entitas yang terdaftar di JII dan hanya berimbas pada turunnya harga saham (cnbcindonesia.com, 2020).

\section{Quantitative Screening Entitas yang terdaftar di JII}

Quantitative screening entitas sangat berhubungan dengan keuangan entitas. Berdasarkan aturan yang telah ditetapkan, entitas yang masuk ke dalam daftar efek syariah adalah entitas yang memiliki persentase utang bunga atas total asset tidak lebih dari $45 \%$ dan persentase pendapatan non halal terhadap total pendapatan tidak lebih besar dari 5\%. Persentase utang bunga dan pendapatan non halal entitas yang terdaftar di JII 2015 - 2019 disajikan pada tabel 3.

Tabel 3. Persentase Utang Berbasis Bunga dan Pendapatan Non Halal pada Entitas yang terdaftar di JII Tahun 2015 - 2019

\begin{tabular}{|c|c|c|c|c|c|c|c|c|c|c|}
\hline \multirow{3}{*}{$\begin{array}{l}\text { Kode } \\
\text { Entitas }\end{array}$} & \multicolumn{10}{|c|}{$\begin{array}{c}\text { Persentase Utang Berbasis Bunga (UBB) atas Total Aset }\left(\frac{\text { UBB }}{\text { Total Aset }}\right) \text { dan } \\
\text { Persentase Pendapatan Non-Halal (PNH) }\left(\left(\frac{P N H}{\text { Total Pendapatan }}\right)\right)\end{array}$} \\
\hline & \multicolumn{2}{|c|}{2015} & \multicolumn{2}{|c|}{2016} & \multicolumn{2}{|c|}{2017} & \multicolumn{2}{|c|}{2018} & \multicolumn{2}{|c|}{2019} \\
\hline & \% UBB & $\begin{array}{c}\% \\
\text { PNH }\end{array}$ & \% UBB & $\begin{array}{c}\% \\
\text { PNH }\end{array}$ & \% UBB & $\begin{array}{c}\% \\
\text { PNH }\end{array}$ & $\%$ UBB & $\begin{array}{c}\% \\
\text { PNH }\end{array}$ & \% UBB & $\begin{array}{c}\% \\
\text { PNH }\end{array}$ \\
\hline ADRO & $26.30 \%$ & $0.42 \%$ & $21.49 \%$ & $0.35 \%$ & $20.44 \%$ & $0.46 \%$ & $20.27 \%$ & $0.71 \%$ & $27.12 \%$ & $0.77 \%$ \\
\hline AKRA & $25.36 \%$ & $0.41 \%$ & $25.46 \%$ & $0.36 \%$ & $18.86 \%$ & $0.22 \%$ & $16.70 \%$ & $0.23 \%$ & $21.53 \%$ & $0.17 \%$ \\
\hline ANTM & $33.30 \%$ & $0.64 \%$ & $33.04 \%$ & $3.68 \%$ & $31.31 \%$ & $2.08 \%$ & $29.79 \%$ & $0.66 \%$ & $28.34 \%$ & $0.29 \%$ \\
\hline ASII & $28.24 \%$ & $0.80 \%$ & $26.79 \%$ & $0.91 \%$ & $20.61 \%$ & $0.94 \%$ & $24.79 \%$ & $0.76 \%$ & $26.06 \%$ & $0.80 \%$ \\
\hline BSDE & $22.00 \%$ & $3.81 \%$ & $19.53 \%$ & $3.29 \%$ & $19.76 \%$ & $2.50 \%$ & $26.78 \%$ & $5.45 \%$ & $24.63 \%$ & $6.04 \%$ \\
\hline ICBP & $10.58 \%$ & $0.00 \%$ & $7.02 \%$ & $0.00 \%$ & $7.45 \%$ & $0.89 \%$ & $6.53 \%$ & $0.64 \%$ & $6.09 \%$ & $0.65 \%$ \\
\hline INCO & $6.38 \%$ & $0.17 \%$ & $4.92 \%$ & $0.32 \%$ & $3.42 \%$ & $0.44 \%$ & $1.72 \%$ & $0.58 \%$ & $0.18 \%$ & $0.60 \%$ \\
\hline INDF & $30.00 \%$ & $1.11 \%$ & $27.27 \%$ & $0.99 \%$ & $27.51 \%$ & $0.86 \%$ & $30.60 \%$ & $0.68 \%$ & $23.88 \%$ & $0.71 \%$ \\
\hline KLBF & $2.91 \%$ & $0.56 \%$ & $1.86 \%$ & $0.68 \%$ & $1.98 \%$ & $0.66 \%$ & $2.05 \%$ & $0.59 \%$ & $4.03 \%$ & $0.60 \%$ \\
\hline LPPF & $0.00 \%$ & $0.34 \%$ & $0.00 \%$ & $0.31 \%$ & $0.00 \%$ & $0.38 \%$ & $0.00 \%$ & $0.38 \%$ & $0.00 \%$ & $0.31 \%$ \\
\hline
\end{tabular}




\begin{tabular}{|l|r|r|r|r|r|r|r|r|r|r|} 
PTBA & $11.97 \%$ & $0.00 \%$ & $12.75 \%$ & $0.00 \%$ & $4.43 \%$ & $0.77 \%$ & $3.44 \%$ & $1.22 \%$ & $2.42 \%$ & $1.74 \%$ \\
PTPP & $0.00 \%$ & $0.00 \%$ & $24.46 \%$ & $0.24 \%$ & $20.15 \%$ & $1.45 \%$ & $22.70 \%$ & $1.15 \%$ & $30.67 \%$ & $1.05 \%$ \\
SMGR & $0.00 \%$ & $0.00 \%$ & $14.16 \%$ & $0.69 \%$ & $20.42 \%$ & $0.60 \%$ & $19.28 \%$ & $0.59 \%$ & $35.14 \%$ & $0.54 \%$ \\
TLKM & $0.00 \%$ & $0.00 \%$ & $17.70 \%$ & $1.45 \%$ & $17.87 \%$ & $1.11 \%$ & $21.38 \%$ & $0.77 \%$ & $23.79 \%$ & $0.80 \%$ \\
UNTR & $4.52 \%$ & $0.79 \%$ & $1.26 \%$ & $1.26 \%$ & $5.69 \%$ & $1.54 \%$ & $8.86 \%$ & $0.94 \%$ & $12.61 \%$ & $0.67 \%$ \\
UNVR & $10.81 \%$ & $0.02 \%$ & $14.29 \%$ & $0.02 \%$ & $19.13 \%$ & $0.01 \%$ & $7.67 \%$ & $0.02 \%$ & $19.20 \%$ & $0.03 \%$ \\
WIKA & $17.91 \%$ & $0.44 \%$ & $21.70 \%$ & $0.32 \%$ & $19.73 \%$ & $0.61 \%$ & $22.94 \%$ & $0.96 \%$ & $24.28 \%$ & $0.85 \%$ \\
\hline
\end{tabular}

Sumber: Laporan Tahunan masing-masing entitas

Berdasarkan data tabel 3, dapat dibuktikan bahwa screening syariah telah dilakukan oleh pihak OJK dengan melihat bahwa tidak ada entitas yang memiliki rasio total utang berbasis bunga dibandingkan dengan total asset lebih dari $45 \%$ dan tidak adanya entitas yang memiliki rasio pendapatan non halal dibandingkan dengan total pendapatan lebih besar dari 10\%. Terdapat 17 entitas yang senantiasa berada pada JII selama kurun waktu 2015 hingga 2019. Tren transaksi utang berbasing bunga dan pendapatan berbasis bunga pada beberapa entitas juga mengalami tren penurunan persentase utang berbasis bunga ataupun pendapatan berbasis bunga. Hal ini menunjukkan keseriusan entitas untuk mulai mengurangi transaksi yang mengandung unsur yang haram.

Sumber utang terbesar pada entitas yang terdaftar di JII adalah dari utang bank dan utang usaha. Untuk utang berbasis bunga bersumber dari utang bank, utang sewa pembiayaan, dan utang obligasi. Selain itu, terdapat entitas yang melakukan pinjaman ke perbankan syariah yang disebut dana syirkah temporer, yaitu PT. Semen Indonesia dan PT. United Tractor. Hal ini menandakan bahwa entitas yang masuk ke dalam JII mulai menghindarkan perusasahaanya dari transaksi yang mengandung bunga. Adapun dampak dari utang terhadap perbankan syariah tersebut adalah adanya bagi hasil yang dilaporkan entitas sebagai beban.

Data ini dapat dilihat bahwa terdapat satu entitas yakni Matahari Departemen Store (LPPF) memiliki tingkat presentasi utang berbasis bunga atas total asset adalah $0 \%$. Sementara dalam laporan keuangannya Matahari Departemen Store melakukan pinjaman berbasis bunga. Hal ini dapat dilihat dengan adanya beban bunga pada laporan keuangannya. Namun pinjaman tersebut hanya berlangsung 2 bulan dalam tahun berjalan kemudian entitas 
Mustakim M: Islamic capital market; Sharia Screening.

melunasi utang tersebut. Hal ini menyebabkan utang berbasis bunga tidak tercantum dalam laporan keuangannya, hanya dilampirkaan dalam catatan atas laporan keuangan.

Kriteria quantitave screening di Indonesia memiliki perbedaan pada persentase utang berbasis bunga dan pendapatan non halal dibandingkan dengan negara lainnya (Mifrahi, 2013). Apabila melihat index DJIM (Dow Jones Islamic Market) yang banyak digunakan beberapa negara di dunia, besarnya utang berbasis bunga adalah tidak lebih 33\% (Ardiansyah et al., 2017; Fielnanda, 2017; Mohd-Sanusi et al., 2015). Aturan ini merujuk pada hadis Nabi mengenai pembagian harta yang menyatakan bahwa “... sepertiga, sepertiga itu sudah banyak..." (HR. Muslim). Apabila persentase ini digunakan maka terdapat entitas yang terdaftar di JII yang seharusnya tidak masuk ke dalam saham syariah. Entitas tersebut adalah PT. Aneka Tambang, PT. Indofood CBP Sukses Makmur, PT. Pembangunan Perumahan, dan PT. Semen Indonesia. Idealnya diperlukan keseragaman standar dalam screening syariah dikarenakan landasan dasar regulasi adalah quran dan hadits.

\section{KESIMPULAN}

Berdasarakan hasil penelitan dan pembahasan untuk mengeksplorasi proses screening syariah yang dilakukan pada entitas yang masuk ke dalam daftar efek syariah. Screening syariah pada aspek quantitative dilakukan untuk memastikan perusahan telah mengikuti aturan besaran persentase utang berbasis bunga tidak lebih dari $45 \%$ dan pendapatan non halal tidak lebih dari $5 \%$. Sementara aspek qualitative, perusahaan yang terdaftar merupakan perusahaan bebas dari aktivitas yang diharamkan oleh agama. Berdasarkan data dari laporan tahunan seluruh entitas yang terdaftar dalam JII tahun 2015 - 2019 terdapat 30 entitas paling likuid, namun dari entitas tersebut terdapat beberapa yang keluar masuk dari daftar listing sehinggaa hanya 17 entitas yang dapat di analisis datanya. Entitas tersebutlah yang dinyatakan telah patuh terhadap screening syariah pada aspek quantitative dan qualitative.

Pelaksanaan screening syariah bukannya tanpa keterbatasan, kritik dan masukan. Penetapan persentase pada aspek quantitative, dimana besaran persentase toleransi sebesar $45 \%$ tingkat utang bunga dirasa masih cukup tinggi dibanding indeks negara lain. Sementara pada aspek qualitative, screening masih terbatas pada halal dan haram kegiatan utama entitas. Padahal masih banyak hal yang telah diatur di dalam Islam, misalnya tanggung jawab sosial lingkungan 
dan etika dalam investasi yang idealnya dapat menjadi dasar penilaian entitas. Kedepannya diperlukan aturan yang seragam antara negara dikarenakan landasan aturan pasar modal syariah diseluruh dunia adalah sama yakni quran dan hadits.

\section{DAFTAR PUSTAKA}

Ardiansyah, M., Qizam, I., \& Qoyum, A. (2017). Telaah kritis model screening saham syariah menuju pasar tunggal ASEAN. IJTIHAD Jurnal Wacana Hukum Islam Dan Kemanusiaan, 16(2), 197. https:// doi.org/10.18326/ijtihad.v16i2.197-216

Ayedh, A. M. A., Shaharuddin, A., \& Kamaruddin, M. I. H. (2019). Shariah Screening Methodology: Does It 'Really' Shariah Compliance? Iqtishadia, 12(2), 144. https://doi.org/10.21043/iqtishadia.v12i2.5573

cnbcindonesia.com. (2020). Heboh Unilever Dukung LGBT, Begini Pergerakan Harga Sahamnya. Www.Cnbcindonesia.Com. https://www.cnbcindonesia.com/market/20200625151036-17168033/heboh-unilever-dukung-lgbt-begini-pergerakan-harga-sahamnya

Derigs, U., \& Marzban, S. (2008). Review and analysis of current Shariahcompliant equity screening practices. International Journal of Islamic and Middle Eastern Finance and Management, 1(4), 285-303. https://doi.org/10.1108/17538390810919600

Fielnanda, R. (2017). Konsep Screening Saham Syariah di Indonesia. AL-FALAH : Journal of Islamic Economics, 2(2). https://doi.org/10.29240/jie.v2i2.255

Firmansyah, E. A. (2017). Seleksi Saham Syariah: Perbandingan Antara Bursa Efek Indonesia Dan Malaysia. Jurnal Inspirasi Bisnis Dan Manajemen, 1(1), 1. https://doi.org/10.33603/jibm.v1i1.480

Mifrahi, M. N. (2013). Perbandingan Kinerja Saham Syariah Berbasis Syariah Stock Screening Yang Berlaku Di Indonesia, Malaysia Dan Gabungan. Ekonomi Dan Bisnis Islam, VII(2), 214-232.

Mohd-Sanusi, Z., Ismail, R., Hudayati, A., \& Harjito, D. A. (2015). Screening process of Shariah-compliant companies: The relevance of financial risk management. International Journal of Economics and Management, 9(1), 177195. 
Mustakim M: Islamic capital market; Sharia Screening.

Otoritas Jasa Keuangan, R. (2015). Otoritas jasa keuangan republik indonesia.

Pok, W. C. (2012). Analysis of Syariah quantitative screening norms among Malaysia Syariah-compliant stocks. Investment Management and Financial Innovations, 9(2), 69-80.

Ramdani, L. A., \& Ahmad Amir Aziz. (2018). Telaah Perbandingan Model Business Screening Dan Financial Screening Indeks Saham Syariah Global. Iqtishaduna: Jurnal Ekonomi E Keuangan Islam, 9(1).

Syariah, D. N. (2003). Pasar Modal dan Pedoman Umum Penerapan Prinsip Syariah di Bidang Pasar Modal.

Wilson, R. (1997). Islamic finance and ethical investment. International Journal of SocialEconomics,24(11),1325-1342.

https://doi.org/10.1108/03068299710193624

Ardiansyah, M., Qizam, I., \& Qoyum, A. (2017). Telaah kritis model screening saham syariah menuju pasar tunggal ASEAN. IJTIHAD Jurnal Wacana Hukum Islam Dan Kemanusiaan, 197. https://doi.org/10.18326/ijtihad.v16i2.197-216

Ayedh, A. M. A., Shaharuddin, A., \& Kamaruddin, M. I. H. (2019). Shariah Screening Methodology: Does It 'Really' Shariah Compliance? Iqtishadia, 12(2), 144. https://doi.org/10.21043/iqtishadia.v12i2.5573

cnbcindonesia.com. (2020). Heboh Unilever Dukung LGBT, Begini Pergerakan Harga Sahamnya. Www.Cnbcindonesia.Com. https://www.cnbcindonesia.com/market/20200625151036-17168033/heboh-unilever-dukung-lgbt-begini-pergerakan-harga-sahamnya

Derigs, U., \& Marzban, S. (2008). Review and analysis of current Shariahcompliant equity screening practices. International Journal of Islamic and Middle Eastern Finance and Management, 1(4), 285-303. https://doi.org/10.1108/17538390810919600

Fielnanda, R. (2017). Konsep Screening Saham Syariah di Indonesia. AL-FALAH : Journal of Islamic Economics, 2(2). https:/ / doi.org/10.29240/jie.v2i2.255

Firmansyah, E. A. (2017). Seleksi Saham Syariah : Perbandingan Antara Bursa Efek Indonesia Dan Malaysia. Jurnal Inspirasi Bisnis Dan Manajemen, 1(1), 1. https://doi.org/10.33603/jibm.v1i1.480

Mifrahi, M. N. (2013). Perbandingan Kinerja Saham Syariah Berbasis Syariah Stock Screening Yang Berlaku Di Indonesia, Malaysia Dan Gabungan. 
Ekonomi Dan Bisnis Islam, VII(2), 214-232.

Mohd-Sanusi, Z., Ismail, R., Hudayati, A., \& Harjito, D. A. (2015). Screening process of Shariah-compliant companies: The relevance of financial risk management. International Journal of Economics and Management, 9(1), 177195.

Otoritas Jasa Keuangan, R. (2015). Otoritas jasa keuangan republik indonesia.

Pok, W. C. (2012). Analysis of Syariah quantitative screening norms among Malaysia Syariah-compliant stocks. Investment Management and Financial Innovations, 9(2), 69-80.

Ramdani, L. A., \& Ahmad Amir Aziz. (2018). Telaah Perbandingan Model Business Screening Dan Financial Screening Indeks Saham Syariah Global. Iqtishaduna: Jurnal Ekonomi \& Keuangan Islam, 9(1).

Syariah, D. N. (2003). Pasar Modal dan Pedoman Umum Penerapan Prinsip Syariah di Bidang Pasar Modal.

Wilson, R. (1997). Islamic finance and ethical investment. International Journal of SocialEconomics,24(11),1325-1342. 